\title{
ALQURAN DALAM PERDEBATAN \\ PEMAHAMAN TEKSTUAL DAN KONTEKSTUAL
}

\author{
M. Sadik \\ STAIN Datokarama Palu, Jl. Diponegoro 23 Palu \\ e-mail:mohsadik@ymail.com
}

\begin{abstract}
The Qur'an, the holy scripture of the Muslims, never changes since its revelation. However, qur'anic exegesis, as the results of brilliant thoughts of the interpreter can only differ from one another. The difference of qur'anic exegesis may be brought about by methods of interpreting the qur'anic verses. Generally speaking, there are method of interpreting the qur'anic verses; textual interpretation and contextual interpretation. These two methods of interpretation have been employed from the time of the Prophet Muhammad to the present time.
\end{abstract}

$$
\begin{aligned}
& \text { ألقرأن, الكتاب المقدس عند المسلمين, غير قابل للتغير منذ بدء } \\
& \text { نزوله. لكن التفسيركنتيجة إجتهاد المفسرين قابل للإختلاف بين } \\
& \text { مفسر و مفسر اخر. يبدو هذا الإختلاف بسبب اختلاف طرق } \\
& \text { مستعملة بينهم فى تفسير ايات القرأن. إذن, هنالك طرق و مناهج } \\
& \text { فى تفسير القرأن واهمها المنهج الظاهري و المنهج الظروفى. } \\
& \text { هذان المنهجان قد استعملا منذ عصر النبى حتى عصرنا الحاضر. }
\end{aligned}
$$

Kata Kunci: Alquran, pemahaman tekstual, pemahaman kontekstual 


\section{PENDAHULUAN}

Diakui secara teologis, sosiologis, dan historis bahwa perbedaan pendapat di kalangan pemikir muslim adalah suatu fakta yang tak terbantahkan. Dalam Islam, perbedaan pendapat adalah sesuatu yang lumrah. Bahkan dapat dikatakan bahwa perbedaan pendapat telah berlangsung sejak masa Rasulullah saw. Namun perbedaan itu disikapi secara dewasa oleh para sahabatnya. Mereka saling menghormati dan tidak memaksakan pendapat mereka kepada yang lain untuk diikuti. Sikap kedewasaan seperti ini juga diwarisi oleh para ulama yang datang kemudian. Sikap tersebut misalnya, tergambar dari ungkapan yang bijaksana "pendapat kami benar tetapi mengandung kemungkinan salah, dan pendapat selain kami salah tetapi mengandung kemungkinan benar".

Bila ditelusuri lebih jauh, penyebab terjadinya perbedaan pendapat di kalangan pemikir muslim, maka dapat disimpulkan bahwa hal itu muncul karena setidaknya dua faktor; pertama, karena faktor eksternal, yaitu: faktor politik, lingkungan, budaya, dan sosial; kedua, faktor internal, yaitu faktor paradigma sang pemikir dan faktor teks (wahyu) itu sendiri. Dalam hal ini, Alquran yang memiliki dimensi hammalah li wujûh atau yahtamilu wujûh al-ma'na (mengandung berbagai kemungkinan makna).

Sebagaimana halnya teks yang lain, teks Alquran dan hadispetunjuk dan sumber hukum Islam-terkadang menimbulkan perbedaan pendapat, disebabkan oleh dua faktor seperti yang disebutkan di atas, yaitu faktor ekternal dan intenal teks. Di antara faktor internal teks adalah sikap yang berbeda dari sang mufasir. Sikap atau paradigma yang berbeda, misalnya, pemahaman yang menggunakan paradigma tekstual, tentu akan menimbulkan interpretasi yang berbeda dengan pemahaman yang menggunakan paradigma kontekstual, bahkan mungkin bertolak belakang sama sekali. Paradigma pemahaman tekstual dan kontekstual telah berlangsung sejak awal dan telah menjadi diskursus yang sangat menarik, dan lebih khusus ketika dikaitkan dengan ayat dan hadis yang bersifat suci, mutlak, dan universal.

Berdasarkan latar belakang di atas, masalah pokok yang akan dikaji dalam tulisan ini adalah problematika pemahaman tekstual dan pemahaman kontekstual. Masalah pokok tersebut kemudian 
dijabarkan ke dalam beberapa sub permasalahan, yaitu: (1) apa yang dimaksud dengan pemahaman tekstual dan pemahaman kontekstual; (2) sejak kapan berlangsungnya pemahaman tekstual dan pemahaman kontekstual; dan (3) sejauhmana implikasi pemahaman tekstual dan pemahaman kontekstual.

\section{PENGERTIAN TEKSTUAL DAN KONTEKSTUAL}

Secara etimologis, tekstual berasal dari kata benda bahasa Inggeris "text", yang berarti isi, bunyi, dan gambar-gambar dalam sebuah buku (Echols \& Shadily, 1989:584). Secara terminologis, pemahaman tekstual adalah pemahaman yang berorientasi pada teks dalam dirinya (Gusmian, 2003:248). Oleh karena itu, lewat pendekatan ini, wahyu dipahami melalui pendekatan kebahasaan, tanpa melihat latar sosio-historis, kapan dan di mana wahyu itu diturunkan.

Sedangkan kontekstual, secara etimologis, berasal dari kata benda bahasa Inggeris "context", yang berarti "suasana", "keadaan" (Echols \& Shadily, 1989:143). Dalam penjelasan lain disebutkan ia berarti; pertama, "bagian dari teks atau pernyataan yang meliputi kata atau bagian tertulis tertentu yang menentukan maknanya; dan kedua, situasi di mana suatu peristiwa terjadi". Kontekstual, berarti sesuatu yang berkaitan dengan atau bergantung pada konteks. Jadi, pemahaman kontekstual adalah pemahaman yang didasarkan bukan hanya pada pendekatan kebahasaan, tetapi juga teks dipahami melalui situasi dan kondisi ketika teks itu muncul, dalam hal ini "wahyu".

Namun, menurut (Gusmian, 2003:58), metode kontekstual yang masih dalam taraf memperhatikan latar sosio-historis ketika wahyu diturunkan, baru dapat disebut sebagai metode pemahaman tekstualreflektif. Analisisnya, biasanya cenderung bergerak dari refleksi (teks) ke praksis (konteks). Muaranya, masih bersifat kearaban, sehingga pengalaman lokal bagi seorang mufasir berada tidak menempati posisi yang signifikan atau bahkan sama sekali tidak punya peran. Baginya, metode kontekstual, adalah metode selain berorientasi pada konteks suatu teks, juga berorientasi pada konteks pembaca (penafsir) teks Alquran.

Sejalan dengan Gusmian, Noeng Muhadjir sebagaimana dikutip Ahmad Syukri Saleh menulis, istilah kontekstual sedikitnya mengandung tiga pengertian: (1) upaya pemaknaan dalam rangka 
mengantisipasi persoalan dewasa ini yang umumnya mendesak, sehingga arti kontekstual identik dengan situasional; (2) pemaknaan yang melihat keterkaitan masa lalu, masa kini, dan masa mendatang; di mana sesuatu akan dilihat dari sudut makna historis dulu, makna fungsional saat ini, dan memprediksikan makna (yang dianggap relevan) di kemudian hari; dan (3) mendudukkan keterkaitan antara yang sentral dan periferi, dalam arti yang sentral adalah teks Alquran dan yang periferi adalah terapannya. Selain itu, yang terakhir ini, juga dapat berarti mendudukkan Alquran sebagai sentral moralitas (Saleh, 2007:58).

Dengan demikian, pemahaman kontekstual adalah pemahaman yang berorientasi pada latar belakang sosio-historis di mana teks muncul dan diproduksi menjadi variabel penting. Selanjutnya, ditarik ke dalam konteks pembaca (penafsir) di mana ia hidup dan berada, dengan pengalaman budaya, sejarah dan sosialnya sendiri. Jadi, pemahaman kontekstual, sifat gerakannya adalah dari bawah ke atas; dari praksis (konteks) menuju refleksi (teks). Teks dalam pendekatan ini hanya dijadikan sebagai variabel penting dalam proses kritik sosial. Oleh karena itu, persoalannya adalah bagaimana teks wahyu hadir di tengah masyarakat, lalu dipahami, ditafsirkan, diterjemahkan, dihayati, dan didialogkan dalam rangka menghadapi realitas sosial dewasa ini.

Berdasarkan keterangan di atas, terlihat bahwa pengertian pemahaman kontekstual mengalami perkembangan-dari hanya melihat konteks ketika wahyu turun-hingga melihat konteks sang penafsir. Bahkan perkembangan terakhir ia telah menjadi suatu "metode penafsiran yang kontemporer". Hal ini bisa dilihat dalam klasifikasi tafsir kontemporer, yang dipilah menjadi lima metode tafsir, yaitu metode global, analitis, perbandingan, tematik, dan kontekstual (Saleh, 2007:45).

Kehadiran metode kontekstual ini setidaknya dipicu oleh kekhawatiran yang akan ditimbulkan ketika penafsiran Alquran dilakukan secara tekstual, dengan mengabaikan situasi dan latar belakang turunnya suatu ayat sebagai data yang penting. Dalam kaitan ini, Muhammad 'Abduh (w. 1905 M), seperti dikutip Munawir Sjadzali dan Ahmad Syukri Saleh, mengingatkan agar berhati-hati dalam membaca karya-karya tafsir terdahulu, karena penulisannya 
berlangsung dalam suasana dan tingkat intelektual masyarakat yang belum tentu sama dengan zaman sekarang. Oleh karena itu, 'Abduh menganjurkan agar mengkaji langsung pesan Alquran dan jika memungkinkan membuat karya tafsir sendiri. Namun, untuk mewujudkannya, ia harus memiliki kemampuan bahasa yang memadai, memahami sejarah nabi terutama situasi kultural masyarakat ketika Alquran diturunkan, dan menguasai sejarah umat manusia umumnya (Sjadzali dalam Baqir \& Basri, 1988:121).

Dibandingkan dengan pemahaman tekstual, pemahaman kontekstual diharapkan dapat mengantarkan wahyu lebih membumi, lebih hidup, dan lebih elastis dalam rangka menjawab problema kemasyarakatan yang berubah setiap saat. Di mana perubahan realitas berjalan secara alami dan berlangsung begitu cepat sehingga ia digambarkan seperti perubahan air sungai yang terus mengalir. Maksudnya, meskipun seandainya seseorang mandi di dalam sungai yang sama, sesungguhnya air yang digunakan, bukan lagi air yang digunakan kemarin.

Sekedar contoh, model tafsir yang menggunakan pemahaman kontekstual adalah tafsir "Argumen Kesetaraan Gender; Perspektif alQuran" oleh Nasaruddin Umar. Buku ini melakukan kajian kritis terhadap anggapan-anggapan yang sudah baku tentang supremasi lakilaki atas perempuan dengan menyandarkan pada dalil-dalil keagamaan, dengan melakukan "imajinasi sosio-historis" mengenai kondisi masyarakat Arab pada abad VI M., ketika Alquran diwahyukan. Teks-teks Alquran yang berkaitan dengan gender dapat disalahpahami tanpa memahami latar belakang sosial budaya masyarakat Arab tersebut.

\section{DARI TEKS HINGGA KONTEKS}

Pertanyaan yang segera muncul, adalah sejak kapan munculnya pemahaman tekstual dan pemahaman kontekstual dalam Islam ?

Secara historis, dapat dikatakan bahwa kedua pola pemahaman, tekstual dan kontekstual dalam Islam, telah ada sejak awal, bahkan sejak zaman Rasulullah saw. Sebagai bukti, dalam riwayat diceritrakan, bahwa ketika Rasulullah mengirim sahabat-sahabat ke luar, pergi ke perkampungan "Banî Qhurayz $\square a h$ ". Rasulullah saw bersabda Lâ Yusallîna Ahadukum illâ fî̀ Banî Qhurayz $\square$ ah. 
janganlah salah seorang dari kalian melaksanakan salat kecuali di Banî Qhurayz $\square a h)$. Ternyata dalam perjalanan hari itu, malam hampir tiba, tetapi mereka belum juga tiba di perkampungan Banî Qhurayz $\square$ ah. Menyikapi sabda rasul di atas, para sahabat terbagi ke dalam dua kelompok. Pertama, sebagian sahabat tidak salat kecuali setelah mereka tiba di Banî Qhurayz $\square$ ah, meskipun waktu asar telah habis. Kedua, sebagian yang lain melakukan salat, meskipun belum sampai di Banî Qhurayz $\square$ ah. Anehnya, ketika para sahabat melapor kepada Rasulullah saw. tentang pengalaman mereka dalam perjalanan, ternyata keduanya mendapatkan pengakuan atau legitimasi dari Rasulullah saw. Artinya, keduanya dibenarkan, tanpa mempersalahkan kedua sikap tersebut (Al-Zarqanî, t.th.:36).

Dari riwayat di atas, dapat ditegaskan bahwa pertama, pernyataan rasul dipahami oleh para sahabat ke dalam dua pola pemahaman. Sebagian memahaminya secara tekstual, sementara sebagian yang lain secara kontekstual. Bagi mereka yang memahaminya secara tekstual, atau memahaminya secara tersurat, tidak melaksanakan salat kecuali setelah tiba di perkampungan Banî Qhurayz $\square a h$, berdasarkan "isi" atau "bunyi teks" itu sendiri. Sedangkan, mereka yang memahaminya secara kontekstual atau memahami yang tersirat, yaitu memahami "semangat" dan "tujuan" dari bunyi teks, yaitu mereka menganggap larangan salat kecuali di Banî Qhurayz $\square$ ah, hanya bermaksud supaya mereka bergegas dalam perjalanan agar mereka cepat tiba, bukan larangan salat secara mutlak. Oleh karena itu, mereka melakukan salat meskipun belum sampai di Banî Qhurayz $\square$ ah, kedua, ligitimasi rasul menunjukkan bahwa pemahaman tekstual dan pemahaman kontekstual dapat dipakai dan dibenarkan untuk memahami wahyu (Alquran dan hadis), dan ketiga, perbedaan pemahaman atau penafsiran dalam masalah agama karena perbedaan pendekatan, bukan merupakan hal yang tabu, bahkan mungkin dapat dikatakan bahwa perbedaan pendapat dalam masalah agama, adalah termasuk dalam kerangka "pemeliharaan sunah Rasulullah saw.”.

Bukti lain, berdasarkan riwayat yang di-takhrij oleh alBayhaqqî, dari Abî 'Imrân; bahwa tatkala pasukan Islam (sahabat) berhadap-hadapan dengan pasukan musuh dalam pertempuran Costantinia, tiba-tiba seorang di antara mereka keluar, dan maju 
menyerbu pasukan musuh (Romawi) seorang diri, sehingga ia gugur sebagai seorang syahid. Para sahabat yang menyaksikan, serentak berteriak dan berkata; subhanallah (Maha Suci Allah), ia telah melemparkan dirinya ke dalam kebinasaan. Sementara Allah swt. telah berfirman; "Dan infakkanlah (hartamu) di jalan Allah, dan janganlah kamu jatuhkan (diri sendiri) ke dalam kebinasaan dengan tangan sendiri, dan berbuat baiklah. Sungguh, Allah menyukai orangorang yang berbuat baik'(Q.S. 2:195). Mendengar perkataan itu, Abû Ayyub al-Ans $\square$ ârî berkata; sungguh kalian telah menafsirkan ayat itu demikian, pada hal ayat tersebut turun berkaitan dengan keadaan kami orang-orang Anshar. Ketika Allah memuliakan agama-Nya, banyak orang-orang yang masuk Islam, kami orang-orang Anshar berkata dalam hati, sungguh harta kami telah hilang, maka tibalah saatnya pergi mengurusnya. Dalam situasi seperti itulah ayat tersebut turun. Karena itu, kebinasaan yang dimaksudkan adalah niat atau keinginan untuk pergi mengurusi harta-harta kami. Untuk itu, kami diperintahkan untuk tetap berjuang, dan Abû Ayyub al-Ans $\square$ ârî senantiasa memperjuangkan agama sampai akhir hayatnya (AlKandahlawiy, 2004:238).

Berdasarkan riwayat di atas, terjadi pemahaman yang berbeda. Sahabat yang menggunakan pemahaman tekstual menafsirkan Q.S. 2:195 secara literal atau tersurat. Secara tekstual, mereka menafsirkannya bahwa orang yang mati karena menyerbu pasukan musuh seorang diri-meskipun dalam rangka memperjuangkan agamaadalah termasuk orang yang melemparkan diri ke dalam kebinasaan yang dilarang oleh Allah swt. sebagaimana bunyi tekstual ayat. Sementara Abû Ayyub al-Ans $\square$ ârî menggunakan pemahaman kontekstual, yaitu mengaitkannya dengan konteks turunnya ayat sehingga ayat tersebut bermakna kami (orang-orang Anshar) yang hanya berniat dalam hati, ingin pergi mengurus pertanian, perdagangan, pekerjaan, rumah, anak, istri, keluarga, dan harta, lalu cuti sementara waktu meninggalkan perjuangan agama bersama Rasulullah, karena telah ada orang-orang yang baru masuk Islam sebagai pengganti kami, maka itulah maksud ayat tersebut"melemparkan diri ke dalam kebinasaan". Ringkasnya, secara kontekstual ayat tersebut bermakna meninggalkan perjuangan agama 
karena alasan kesibukan dan urusan yang bersifat keduniaan, maka itulah maksud ayat tersebut, melemparkan diri ke dalam kebinasaan.

Dalam perspektif “Jama'ah Tabligh", untuk menyebut sekedar contoh, ayat ini dijadikan dasar untuk memberi motivasi orang-orang Islam untuk berkorban, meninggalkan pekerjaan, perdagangan, pertanian, rumah, keluarga, anak, istri dan sebagainya, pergi sementara waktu ( $k h u r \hat{u j}$ ) dalam rangka memperjuangkan agama dan mendakwahkannya, serta meninggikan kalimat Allah (li i'lâi kalimat Allâh) di muka bumi. Namun, oleh sebagian orang enggan pergi, justru menjadikan ayat tersebut (QS.2:195) sebagai alasan utama. Mereka memandang, bahwa meninggalkan pekerjaan, perdagangan, pertanian, rumah, keluarga, anak, istri dan sebagainya adalah berarti menjerumuskan diri ke dalam kebinasaan. Pada hal secara kontekstual, sesungguhnya keengganan mereka berkorban-harta, waktu, dan diri- dengan meninggalkan semua kecintaan dan kesenangannya, lalu pergi memperjuangkan agama sementara waktu, justru sesungguhnya merekalah yang telah melemparkan diri ke dalam kebinasaan, yang dilarang oleh Allah swt. dalam ayat tersebut.

Pemahaman tekstual, tampaknya kemudian mengkristal menjadi suatu metode, yang oleh Al-Qard $\square$ âwî disebutnya dengan "madrasah $z \square$ ahiriyyah", sebagai tandingan atau lawan dari "madrasah ta' $t \square \hat{\imath} l l i$ al-nus $\square \hat{u s} \square$ " (penganulir teks). Menurutnya, madrasah $z \square$ ahiriyyah adalah madrasah yang lebih bergantung kepada teks-teks partikular, memahaminya dengan pemahaman literal dan jauh dari maksudmaksud syari'at yang ada di belakangnya. Mereka mengingkari adanya ta'lil (alasan), hikmah atau maksud, dan juga qiyas (analogi) di dalam hukum (Al-Qard $\square$ âwî, 2007:38).

Di sisi lain, pemahaman kontekstual, juga tampaknya berkembang menjadi suatu metode, yang oleh Al-Qard $\square$ âwî menyebutnya sebagai madrasah ta't $\square \hat{\imath l}$ li al-nus $\square \hat{u} s \square$ (penganulir teks). Madrasah ini mengklaim bahwa mereka lebih bergantung kepada maksud-maksud syari'at dan ruh agama dengan menganulir teks-teks partikular di dalam Alquran dan sunah. Mereka memandang bahwa agama adalah substansi bukan simbol, atau isi bukan bentuk (Al-Qard $\square$ âwî, 2007:38). 


\section{IMPLIKASI PEMAHAMAN TEKSTUAL DAN KONTEKSTUAL}

Dari pembahasan sebelumnya, telah tampak bagaimana implikasi yang ditimbulkan oleh pemahaman tekstual dan pemahaman kontekstual. Untuk memperjelas hal tersebut, berikut ini akan diberikan beberapa contoh pemahaman tekstual dan pemahaman kontekstual.

Pemahaman kontekstual dapat dilihat misalnya, pada reformulasi tafsir feminis yang digagas oleh para tokoh-tokohnya, seperti Riffat Hassan, Fatimah Mernissi, Amina Wadud, dan Asghar Ali Engineer. Mufasir feminis ini tampaknya berangkat dari suatu asumsi pokok, bahwa laki-laki dan perempuan setara (equal) dihadapan Tuhan, yang membedakan keduanya hanyalah tingkat ketakwaannya, sebagaimana ruh atau semangat Islam. Tetapi, mengapa dalam penafsiran Alquran hasil produk ulama klasik seringkali kurang mencerminkan keadilan gender? Misalnya, dalam hal pembagian warisan, laki-laki mendapat dua kali bagian perempuan (mallempai oroanewe ma'jujungngi makkunraiye). Pada hal, situasi dan kondisinya sangat berbeda dengan 15 abad yang lalu ketika Alquran diturunkan.

Penafsiran yang kurang mencerminkan ketidakadilan gender tersebut, jika ditelusuri secara seksama, maka setidaknya dipicu oleh dua faktor, yaitu: (1) faktor internal teks yang terbentuk dalam budaya patriarki, misalnya; mengapa kata "Allâh" dalam bahasa Alquran, kata gantinya selalu "huwa" (dia) yang merujuk kepada jenis laki-laki (muz $\square$ akkar), bukan "hiya" (dia) yang merujuk kepada jenis perempuan (muannath); dan (2) faktor mufasir Alquran, di mana pada umumnya mufasir adalah berjenis kelamin laki-laki, sehingga seringkali tidak mengakomodir kesadaran perempuan.

Dalam kitab-kitab tafsir klasik, tampaknya penafsiran secara literalistik-skripturalistik atas ayat-ayat Alquran tentang gender adalah cukup dominan. Ayat-ayat yang secara harfiah menegaskan keunggulan laki-laki atas perempuan cenderung dipahami secara tekstual-literalistik pula oleh para mufasir klasik, dengan mengabaikan pendekatan historis-kontekstual terhadap teks-teks Alquran sehingga hasilnya adalah sebuah penafsiran yang bias patriarki. 
Ayat "al-rijâl qawwâmûna "alâ al-nisâ"” misalnya, dipahami sebagai penegasan atas keunggulan kaum laki-laki daripada kaum perempuan. Kata "qawwâmûn" diartikan "penanggung jawab, penguasa, pemimpin, penjaga atau pelindung perempuan”. Alasan mereka, antara lain seperti disebutkan oleh pemikir Mu'tazilah, AlZamakhsyari, ia mengatakan bahwa teks ayat di atas menunjukkan bahwa keunggulan laki-laki atas perempuan adalah bersifat alamiah, bukan karena paksaan. Keunggulan itu adalah karena memiliki kelebihan penalaran ( $a l$-' $a q l)$, memiliki tekad yang kuat (al-hazm), keteguhan (al-'azm), kekuatan fisik (al-quwwah), kemampuan menulis (al-kitâbah) dan keahlian menunggang kuda serta memanah (al-furusiyyah wa al-ramyu) (Al-Zamakhsarî, 1977:525).

Sementara Rashîd Ridâ menyebutkan bahwa kelebihan laki-laki atas perempuan, adalah bahwa laki sejak penciptaan sudah diberi kekuatan dan kemampuan. Laki-laki adalah lebih tegap, lebih sempurna dan lebih kuat. Akibat kesempurnaan fisik ini, laki-laki memiliki kesempurnaan akal dan kejernihan pandangan, yang melahirkan kelebihan kasbî. Laki-laki lebih dapat berusaha, berinovasi dan bergerak. Oleh karena itu, laki-laki dituntut memberi nafkah pada perempuan, menjaga, dan memimpinnya (Ridâ, 1973:6970). Dengan karakteristik laki-laki dan perempuan yang berlainan itulah, para mufasir klasik menyimpulkan bahwa laki-laki memang lebih unggul daripada perempuan. Posisi laki-laki dan perempuan sudah tidak setara secara alamiah dengan adanya keunggulankeunggulan tersebut.

Berbeda dengan mufasir klasik, para mufasir feminis kemudian menggugat penafsiran klasik yang sarat dengan superioritas laki-laki atas perempuan tersebut. Mereka memiliki pandangan bahwa lakilaki adalah setara (sederajat) dengan perempuan, bukan subordinat, dan bukan pula sebagai lawan. Mereka menyadari bahwa agama Islam dengan kitab sucinya, Alquran, wujud dengan membawa missi tegaknya keadilan universal, tanpa memandang suku, ras, kedudukan sosial, dan jenis kelamin (Abdul Mustaqim, 2003:54).

Karena itu, para mufasir feminis dengan karya-karyanya menekankan status kesetaraan laki-laki dan perempuan dalam Islam. Keunggulan seseorang dalam Islam, sama sekali tidak terkait dengan 
persoalan gender, namun lebih pada keunggulan ruhaniah dan spiritualitasnya di hadapan Tuhan. Firman Allah: "inna akramakum 'inda Allâh atqâkum” selalu dikutip untuk menunjukkan hal tersebut (Abdul Mustaqim, 2003:47). Untuk menggiring kepada paham kesetaraan ini, mereka penafsiran ayat tersebut secara kontekstual yang dilakukan dengan memperhatikan situasi dan kondisi masyarakat saat teks itu muncul. Dengan kata lain, untuk memahami ayat tersebut harus dilihat kembali kondisi perempuan yang saat itu memang hidup dalam suasana sistem patriarilineal. Dengan menghadapkan teks-teks keagamaan dengan kondisi perempuan ketika teks itu muncul, dapat dipetik kesimpulan bahwa status laki-laki dan perempuan adalah setara.

Bagi mufasir feminis, keunggulan laki-laki atas perempuan sebagaimana yang tersurat dalam surah QS. Al-Nisâ' (4:34) tersebut, tidaklah bersifat absolut, melainkan bersifat relatif. Penegasan bahwa laki-laki sebagai qawwâmûn atas perempuan adalah karena pihak pertama memberi nafkah kepada pihak kedua, sebagaimana bunyi lanjutan ayat tersebut, "bimâ anfaqa min amwâlihim". Karena terkait dengan soal pemberian nafkah, maka superioritas itu tidaklah bersifat bawaan sejak lahir, melainkan faktor ekonomis (Abdul Mustaqim, 2003:55).

Dengan demikian, kata ini lebih merupakan pernyataan yang menegaskan pembagian kerja fungsional yang diperlukan untuk mempertahankan keseimbangan dalam masyarakat. Laki-laki yang tidak berkewajiban melahirkan anak diberi tugas untuk memberi nafkah. Sedangkan perempuan dibebaskan dari tugas memberi nafkah agar mereka dapat memenuhi fungsi melahirkan dan mengasuh anak. Laki-laki berfungsi produktif, sementara perempuan reproduktif. Kedua fungsi ini terpisah satu dengan yang lain, namun saling melengkapi dan tidak ada yang lebih tinggi atau lebih rendah. Jadi, perempuan ketika itu hanya berperan dalam hal-hal yang bersifat privat, sementara laki-laki mempunyai peran dalam hal yang bersifat publik. Kondisi itu, kini sudah berubah, di mana kaum perempuan telah mengambil peran publik. Jika dulu mereka duduk manis di rumah, dan ekonomi mereka ditanggung sepenuhnya oleh laki-laki, 
maka sekarang terlihat laki-laki justru mengandalkan ekonominya dari istri (Abdul Mustaqim, 2003:55).

Menurut Syafruddin (1994:6), jika dasar superioritas itu karena faktor ekonomis, kelebihan laki-laki atas perempuan adalah bersifat kasbî. Karena bersifat kasbi, perempuan memperoleh peluang yang sama dengan laki-laki untuk memperoleh superioritasnya dalam kehidupan sosial. Hal ini tidak lepas dari tradisi masyarakat Arab yang memberikan mahar yang mahal dan memberi nafkah kepada perempuan (istri), maka posisi laki-laki menjadi lebih penting. Seandainya yang terjadi adalah sebaliknya, tentu perempuanlah yang akan lebih penting.

Jika keunggulan laki-laki didasarkan pada kecerdasannya, maka mufasir feminis menolaknya. Bukti sejarah menunjukkan bahwa sangat banyak perempuan yang memiliki kecerdasan dan mencapai prestasi sebagaimana halnya laki-laki. 'Aisyah misalnya, pernah menjadi pemimpin perang, di samping seorang istri, ia juga sebagai sahabat nabi yang cerdas, yang meriwayatkan ribuan hadis nabi.

Bagi mufasir feminis, diakui bahwa posisi perempuan dalam kehidupan sosial pada masa nabi menempati kedudukan yang setara dengan laki-laki. Struktur patriarki pada masa jahiliyah dibongkar oleh Islam dengan memberikan hak-hak kepada perempuan yang pada masa sebelumnya tidak diberikan. Perempuan tidak mendapatkan apaapa dalam hal waris di masa jahiliyah, misalnya. Namun, Islam datang lalu memberikannya. Jika pada masa jahiliyah masyarakat Arab membenci kelahiran seorang anak perempuan, Islam justru membenci tradisi masyarakat Arab tersebut dan memberikan janji pahala bagi yang memperlakukan anak perempuan sebagaimana memperlakukan anak laki-laki.

Karena itu, bagi mereka, pembagian warisan dapat digeser menjadi sama besar antara laki-laki dan perempuan karena ide dasarnya adalah keadilan, bukan dari segi satu banding dua. Pembagian satu banding dua pada waktu itu memang dirasa sangat adil. Karena itu, jika ternyata nilai keadilan itu berubah sejalan dengan perubahan sistem nilai yang berlaku di masyarakat, penafsirannya pun harus berubah (Abdul Mustaqim, 2003:xvi) 
Kasus lain, misalnya adalah tentang kedudukan saksi perempuan. Dua saksi perempuan sebanding dengan satu saksi lakilaki. Bagi mufasir feminis, lagi-lagi masalah ini tidak mencerminkan keadilan gender. Asghar Ali Engineer sebagaimana ditulis Abdul Mustaqim mempertanyakan mengapa dua perempuan dianggap sebanding dengan satu laki-laki dalam hal persaksian. Dengan tafsir feminis, penafsiran konvensional ini pun dapat berubah. Melalui metode kontekstual, ayat tersebut jika dirunut pada konteks turunnya ayat (asbâb al-nuzĥl), berbicara mengenai persaksian dalam konteks jual beli (niaga). Sementara mereka ketika itu tidak banyak terlibat dalam menangani persoalan-persoalan niaga, sehingga diasumsikan bahwa persaksian satu perempuan itu kurang valid, dan karenanya diperlukan satu teman lain perempuan untuk memperkuat persaksiannya (Abdul Mustaqim, 2003:xvii).

Jika demikian, masalahnya bukan masalah dua banding satu, tetapi masalahnya adalah masalah profesionalisme, validitas dan kekuatan dalam persaksian. Jika kemudian, kondisi ini berubah dengan suatu kenyataan bahwa banyak kaum perempuan yang profesional dan mampu menangani persoalan-persoalan bisnis, maka seharusnya perempuan disejajarkan dengan kaum laki-laki dalam hal saksi, termasuk saksi dalam perkawinan.

Dengan contoh-contoh di atas, sekali lagi tampak bahwa para mufasir klasik, cenderung memahami ayat-ayat yang bias gender secara tekstualis-skripturalis. Sementara para mufasir feminis, mencoba memahaminya lewat pendekatan kontekstual, dengan cara mendialogkan dengan ruh atau semangat yang ada di balik teks, yaitu menangkap ideal moral yang diinginkan oleh ayat-ayat tersebut. Ideal moral yang dimaksud adalah justice of God (keadilan Tuhan).

Diskursus tentang keadilan Tuhan memang debatable. Jika para mufasir feminis memahami keadilan Tuhan apabila antara perempuan dengan laki-laki sebanding dan sama besar, maka para mufasir klasik memandang bahwa dua banding satu justru disitulah letak keadilanNya.

Untuk menggambarkan keadilan Tuhan dalam pandangan mufasir klasik, diilustrasikan sebagai berikut; jika terdapat harta peninggalan Rp.250.000,-, maka laki-laki mendapat Rp.150.000,-, dan perempuan mendapat Rp.100.000,-. Namun, jika laki-laki kawin dan 
menaikkan belanja, katakan memberi mahar Rp.25.000,-, maka hartanya sudah berkurang menjadi Rp.125.000,-. Sementara perempuan jika ia kawin, maka akan menerima mahar, katakan ia menerima Rp.25.000,-. Ini artinya, harta perempuan bertambah menjadi Rp.125.000,-. Dengan demikian, jumlah harta masingmasing telah menjadi sama besar. Jika demikian, berarti cara pembagian dua banding satu adalah cara yang adil.

Diakui, secara sosio-historis, laki-laki selalu berada pada pihak yang menanggung, sementara perempuan berada pada pihak yang ditanggung. Karena itu, jika laki-laki berkewajiban membayar mahar, perempuan berhak menerima mahar. Jika laki-laki berkewajiban memberi nafkah, maka perempuan berhak menerima nafkah. Menurut hemat penulis, aturan ini bersifat sunnatullah (aturan dasar) dan berlaku umum, namun tidak bersifat mutlak. Jika ternyata keadaan itu telah berubah, pembagian warisan dan saksi dapat saja berubah, tetapi tidak bersifat umum, ia hanya bersifat khusus atau kasuistik. Bahkan bagian perempuan dapat saja lebih banyak dibandingkan dengan bagian laki-laki, yang tentunya dilihat dari kaca mata pertimbangan mas $\square$ lahah (kemaslahatan).

Namun, perlu digarisbawahi, jika pemahaman tekstual yang rigid (kaku), dapat menggiring seseorang kepada pemahaman yang statis, maka pemahaman kontekstual dapat menggiring kepada pemahaman yang dinamis. Jika pemahaman tekstual membawa kepada sikap yang bersifat tradisional dan absolut, maka pemahaman kontekstual membawa kepada sikap yang bersifat liberal dan relatif.

Jika demikian, pola pemahaman tekstual dan pemahaman kontekstual, masing-masing mempunyai kelemahan. Karena itu, perlu ditempuh jalan tengah sebagai sikap yang tawassut $\square$ (moderat). Yaitu, acuan utama terhadap ayat atau hadis yang bersifat $\mathrm{muh} \square \mathrm{kam}$ dan qat $\square$ 'i (jelas dan pasti), tetaplah pemahaman tekstual, meskipun dalam penerapannya dapat berubah, sesuai dengan situasi dan kondisi yang ada. Sementara pemahaman kontekstual dapat digunakan dalam ayat atau hadis yang tidak bersifat muh $\square$ kam dan qat $\square \hat{\imath}$. Dengan sikap ini, kita telah memilih dan memilah mana ayat atau hadis yang bersifat al-thabât, dan mana yang bersifat al-mutaghayyir, mana yang absolut dan mana yang relatif. 


\section{PENUTUP}

Berdasarkan uraian terdahulu, dapat disimpulkan beberapa hal sebagai berikut:

- Pemahaman tekstual adalah pemahaman yang berorientasi terhadap teks dalam dirinya. Analisisnya, mengacu kepada pendekatan kebahasaan. Sedangkan pemahaman kontekstual berorientasi pada konteks teks, baik konteks ketika turunnya ayat atau hadis maupun pada konteks sang penafsir. Analisisnya, mengacu kepada selain pendekatan kebahasaan, juga menggunakan pendekatan sosiologis, historis, dan antropologis. Gerakannya dari bawah ke atas atau dari praksis menuju teks.

- Pemahaman tekstual dan pemahaman kontekstual dalam Islam, telah ada sejak masa Rasulullah saw. Artinya, keduanya telah ada berbarengan dengan munculnya teks wahyu itu sendiri.

- Implikasi pemahaman tekstual dapat menjerumuskan ke dalam pemahaman yang sempit dan kaku, sementara pemahaman kontekstual dapat menggiring kepada pemahaman yang liberal. Akibatnya, tidak ada lagi teks yang sakral, thabât, dan absolut, sehingga bisa berujung pada peminggiran dan pembuangan teks secara keseluruhan.

\section{DAFTAR PUSTAKA}

Gusmian, Islah. 2003. Khazanah Tafsir Indonesia dari Hermeneutika hingga Ideologi. Cet. ke-1. Jakarta: Teraju.

al-Kandahlawî, Muhammad Yûsuf, 2004. Hayât al-Sahâbah. Bairut: Dâr alKitâb al-'Arabî.

Mustaqim, Abdul. 2003. Tafsir Feminis versus Tafsir Patiriarki. Yogyakarta: Sabda Persada.

Ridâ, Rashîd. 1973. Tafsîr al-Manâr. Juz V. Beirut: Dâr al-Fikr.

Saleh, Ahmad Syukri. 2007. Metodologi Tafsir Al-Qur'an Kontemporer dalam Pandangan Fazlur Rahman. Jakarta: Gaung Persada Press.

al-Qardâwî, Yûsuf,. 2007. Dirâsah fì Fiqh Maqâs $\square i d$ al-Sharî'ah. Terjemahan oleh Arif Munandar Riswanto. Fiqh Maqâs $\square i d$ alSharî'ah. Jakarta: Pustaka al-Kautsar.

al-Zamakhsharî, Abû al-Qâsim Jar Allâh, .1977. Al-Kashshaf 'an Haqấ'iq al-Tanzîl wa 'Uyûn al-Aqâwil fî Wujûh al-Ta'wîl. Beirut: Dâr al-Fikr. 
Jurnal Hunafa, Vol. 6, No.1, April 2009: 53-68

al-Zarqânî, Muhammad 'Abd al-'Az $\square$ im. t.th. Manâhil al-'Irfân fi 'Ulûm alQur'ân. Jilid II. Bairut: Dâr al-Fikr.

Echols, John M., \& Shadily, Hasan. 1989. Jakarta: Gramedia. 